\title{
A new species of freshwater amphipod genus Gammarus (Amphipoda: Gammaridae) from Tajikistan (Pamir Mountains)
}

\author{
Новый вид пресноводных амфипод рода Gammarus \\ (Amphipoda: Gammaridae) из Таджикистана (Памир)
}

\author{
Ivan N. Marin ${ }^{1,2}$, Dmitry M. Palatov ${ }^{1,3}$ \\ Иван Н. Марин ${ }^{1,2}$, Амитрий М. Пахатов ${ }^{1,3}$
}

\footnotetext{
${ }^{1}$ A.N. Severtzov Institute of Ecology and Evolution of RAS, Leninsky prosp., 33, Moscow 119071 Russia.

${ }^{2}$ Biological Department, Altai State University, prospect Lenina, 61, Barnaul, 656049 Russia.

${ }^{3}$ Moscow Lomonosov State University, Leninskye gory, 1, Moscow, 119992 Russia.

${ }^{1}$ Институт проблем экологии и эволюции им. А.Н. Северцова РАН, Ленинский просп., 33, Москва 119071 Россия.

${ }^{2}$ Биологический факультет, Алтайский Государственный Университет, пр-т Ленина, 61, Барнаул 656049 Россия.

${ }^{3}$ Московский государственный университет им. М.В. Ломоносова, Ленинские Горы, 1, Москва, 119991 Россия.

E-mail: coralliodecapoda@mail.ru, vanomarin@yahoo.com, triops@yandex.ru
}

KEY WORDS. Gammarus, new species, Gammaridae, freshwater, Gorno-Badakhshan, Tajikistan, Pamir Mountains.

КЛЮЧЕВЫЕ СЛОВА. Gammarus, новый вид, Gammaridae, пресные воды, Горно-Бадахшан, Таджикистан, Памир.

ABSTRACT. A new species of freshwater amphipod, Gammarus martynovi sp.n., from a small thermal spring in the headwaters of a small tributary of the Panj River in Gorno-Badakhshan Autonomous Region of Tajikistan is described based on morphological and molecular genetic data. The new species belongs to the "Gammarus lacustris" species group, but can be clearly separated from other species by the combination of the following features: accessory flagellum of A1 with less than 3 segments (the last is short); dactyli of Pp3-7 almost straight, with a short unguis; posterior margin of P7 straight in distal (2/3) part, with setae; U3 with bristles (plumose setae) and simple setae on edges of both branches; telson lobe with 1-2 apical spines; dorsal setae on urosomites shorter than spines, while distal setae on telson lobes much longer than spines; and 3 retinacules on Pl3. Moreover, this is the first Gammarus species described from Amu Darya basin in the territory of Tajikistan in Pamir Mountains.

How to cite this article: Marin I.N., Palatov D.M. 2020. A new species of freshwater amphipod genus Gammarus (Amphipoda: Gammaridae) from Tajikistan (Pamir Mountains) // Arthropoda Selecta. Vol.29. No.2. P.199-209. doi: 10.15298/arthsel. 29.2.04

РЕЗЮМЕ. Новый вид пресноводных амфипод, Gammarus martynovi sp.n., описывается на основе морфологических и молекулярно-генетических данных из термального источника в верховьях небольшого притока реки Пяндж в Горно-Бадахшанской автономной области Таджикистана. Новый вид относится к группе видов “Gammarus lacustris", но может быть четко отделен от других видов рода по совокупности следующих признаков: в дополнительном жгутике A1 не более трех члеников (последний из них короткий); дактилюсы Рp3-7 почти прямые, с коротким коготком; задний край Р7 прямой в дистальной $(2 / 3)$ части, дистовентральный угол, не образует оттянутой лопасти, вооружен щетинками; U3 с густыми перистыми и простыми щетинками по обоим краям ветвей; доли тельсона с 12 апикальными шипами; щетинки на уросомитах короче шипов, дистальные щетинки долей тельсона значительно длиннее шипов; по 3 ретинакулы на P13. Более того, это первый вид рода Gammarus, описанный в бассейне Амударьи на территории Таджикистана в Памирских горах.

\section{Introduction}

Pamir region and most of the territory of Tajikistan are characterized by high mountain ranges with deep river gorges, which certainly contribute to local allopatric speciation, especially, among aquatic animals. However, only fragmentary data are available on freshwater crustaceans and gammarid amphipods of the region. Four species from three genera of Gammaridae has been described from Tajikistan: Tadzocrangonyx schizurus (Birštein, 1948) described from Gissan (Hissan) Mountains; Comatogammarus ferghanensis (Martynov et Behning, 1948) (=Sarothrogammarus ferghanensis) known from Darvaz mountain ridge, northwards from Kalai-Humb; Tadzhikistania shadini (Birštein, 1948) from Saradzhou River, a tributary of 
the Varzob River and springs near Hodza-obigarm, Obisafet, Kvaka and Gammarus ocellatus Martynov, 1930 from Iskanderkul lake, Gissar (Hissar) Mountains [Birštein, 1948; Martynov, Behning, 1948; after Sidorov et al., 2013]. Later G. ocellatus was synonymous with $G$. lacustris Sars, 1863, and the latter species was also listed from the brackish-water of Shorkul Lake in the Pamir Mountains [Birštein, 1945, 1948]. In addition, Sarothrogammarus ruffoi Karaman, 1971 was described from the Pamir Mountains in Afghanistan (Karaman, 1971), and Birštein [1948] reported on Gammarus subaequalis (Martynov, 1935) from the Gissan (Hissar) Mountains near Dushanbe, but the exact taxonomy of this species is still unclear (see Birštein, 1948; Sidorov, Hou, 2018) and the material described is probably lost. At the same time, the diversity of the genus Gammarus Fabricius, 1775 is obviously high in Tajikistan, and in this article we describe a new species of the genus from a thermal spring located in the headwaters of the Shakhdara, a small tributary of the Panj River in the Pamir Mountains.

\section{Material and methods}

Amphipods were collected by hand net in a small thermal spring Dzhaushangoz $\left(37^{\circ} 21^{\prime} 59.83^{\prime \prime} \mathrm{N} 72^{\circ} 21^{\prime} 55.31^{\prime \prime} \mathrm{E}\right)$ at an altitude of $3357 \mathrm{~m}$ above sea level in Pamir Mountains. Research does not include endangered or protected species. Photographs were made with Olympus ZX10 with digital camera. SEM photographs were made in Electronic Microscopy Laboratory of the Biological Faculty of the Moscow State University using a CamScan S2 microscope. All specimens were preserved and stored in $90 \%$ solution of ethanol for further DNA analysis. The specimens are deposited in the zoological collection of the Zoological Museum of Moscow State University, Moscow, Russia (ZMMU).

To study the taxonomy of the cryptic diversity, a fragment of the mitochondrial gene encoding the cytochrome $\mathrm{c}$ oxidase subunit I gene (COI mtDNA) was amplified, sequenced, and compared. Total genomic DNA was extracted from muscle tissue of abdomen and pereiopods using standard methods and amplified using the universal primers LCO1490 (5'-GGTCAACAAATCATAAAGATATTGG-3') and HC02198 (5'-TAAACTTCAGGGTGACCAAAAAATCA-3') [Folmer et al., 1994]. PCR products were performed under the following conditions: initial denaturation at $96{ }^{\circ} \mathrm{C}$ for $1.5 \mathrm{~min}$ followed by 42 cycles of $95^{\circ} \mathrm{C}$ for $2 \mathrm{~min}, 55^{\circ} \mathrm{C}$ for $35 \mathrm{sec}$, and $72{ }^{\circ} \mathrm{C}$ for $1.5 \mathrm{~min}$, followed by chain extension at $72^{\circ} \mathrm{C}$ for $7 \mathrm{~min}$. The volume of $20 \mathrm{uL}$ of reaction mixture contained $5 \mathrm{uL}$ of total DNA, 10uL of PCR Diluent and $2.5 \mathrm{uL}$ of each primer. Fragment of COI mtDNA gene marker was performed at an annealing primer temperature $59{ }^{\circ} \mathrm{C}$ during $45 \mathrm{sec}$. The resulting aligned sequences of COI mtDNA gene marker, about $650 \mathrm{bp}$ in length, sequences from GenBank (NCBI) and other resources were used for phylogenetic analysis using Maximum-Likelihood (ML) Neighbour-joining (NJ) and Bayesian (BA) algorithms. The best evolutionary substitution model was determined using MEGA 7.0. and jModeltest2.1.141. Phylogenetic analysis was performed using MrBayes v.32.6 for BA, RAxML v.8.2.10 via the Cyber Infrastructure for Phylogenetic Research (CIPRES) portal v.3.1. (www.phylo.org) for ML and
MEGA 7.0 for NJ analysis. An additional dataset of COI mtDNA gene marker used in the study was taken from GenBank (NCBI) and the author's data.

\section{Systematic account}

\author{
Order Amphipoda Latreille, 1816 \\ Family Gammaridae Leach, 1814 \\ Genus Gammarus Fabricius, 1775 \\ Gammarus martynovi sp.n.
}

Figs 1-5.

MATERIAL EXAMINED. Holotype: $\sigma^{7}, 11.0 \mathrm{~mm}$, ZMMU $\mathrm{Mb}-1150$, collected with a fine-mesh hand-net in a rheocrene habitat, $37^{\circ} 21^{\prime} 59.83^{\prime \prime} \mathrm{N} 72^{\circ} 21^{\prime} 55.31^{\prime \prime} \mathrm{E}$, near ruins of the fortress of Deruzh Shakhdara River valley, Roshtqal'a District (or Nohiya-i Roshtqal'a), Gorno-Badakhshan (nowadays the Kuhistani Badakhshan) Autonomous Region, Tajikistan, coll. by D.M. Palatov, 21.06.2012; Paratypes: $0^{1}, 8.0 \mathrm{~mm}$, ZMMU Mb-1151, same data as holotype; $+9.0 \mathrm{~mm}$, ZMMU Mb-1152, same data as holotype; $21 \mathrm{O}^{T} \mathrm{O}^{T}$ and $41 \mathrm{O}++$, same data as holotype.

DESCRIPTION. Head (Fig. 5a) with deep inferior antennal sinus, ultrastructure of surface with distinct pores decorated in rows (Fig. 5b). Eyes ovoid, as long as the diameter of first peduncle segment of antenna 1. Antenna 1 (A1) (Fig. 1a) shorter than the half of body length; setation rather weak, all peduncular segments with sub-distal setae as half as the diameter of the segment (Fig. 1b); article 1 stout, about twice as long as wide; primary flagellum short, about 20 articles; accessory flagellum with 2 large articles and distal article very small (2+1). Antenna 2 (A2) (Fig. 1c) with ventral margins of peduncular segments armed with 2-3 subdistal groups of setae as long as or slightly shorter than the diameter of the segment; setae on dorsal side of the segments shorter than on setae on ventral side; antennal cone curved, noticeably shorter than article 3 ; article 1 stout shorter than long; article 2 about 3.5-4 times as long as wide; article 3 about 6 times longer than wide; flagellum comprising up to 12 segments; calceoli large (Figs $1 d, e$, $5 c$ ).

Left mandible (Fig. 2b, $d$ ) with incisor armed with 5 teeth; lacinia mobilis with 4 dentitions (Fig. 2d). Right mandible (Fig. 2c, e) with 4-dentated incisor, lacinia mobilis bifurcate (Fig. 2e). Maxilla 1 (Fig. 2f, $i$ ) with inner plate bearing 18-20 plumose setae, outer plate with 11 serrated spines (Fig. $2 g$ ); article 2 of palp with 9 sharp spines and 2 stiff-like setae (Fig. $2 h$ ); article 2 of right palp stout, with 5 blunt spines in distal part and 2 stiff setae on outer margin (Fig. 2i). Lower lip (Fig. 2a) without inner lobe. Upper lip (Fig. $2 l$ ) convex, with minute setae on distal part. Maxilla 2 (Fig. 2j): inner plate with a diagonal row of about 20 plumose setae. Maxilliped (Fig. $2 k$ ) with inner plate armed with 3 apical spines and 1 subapical spine, outer plate with a row of about 10 spines on medial margin and 5-7 pectinate apical setae.

Coxal plate 1 (Fig. $1 f$ ) rectangular, with 3 long setae on anterodistal margin and 1 short seta on posterodistal margin. Coxal plate 2 (Fig. 1j) armed with 3 long setae on anterodistal margin and 1 short seta on posterodistal margin. Coxal plate 3 with 1 short setae on anteroventral corner and 3 setae along posteroventral margin (Fig. $3 a$ ). Coxal plate 4 wider in the median part, with 2-3 short setae on anteroventral corner and 7 setae along posteroventral margin (Fig. $3 d$ ). Coxal plates 5-6 bilobated. Anterior lobe of coxal plate 5 small and unarmed or armed with 1 small setae, posterior lobe with 4 setae on posterodistal corner (Fig. 3f). Coxal 

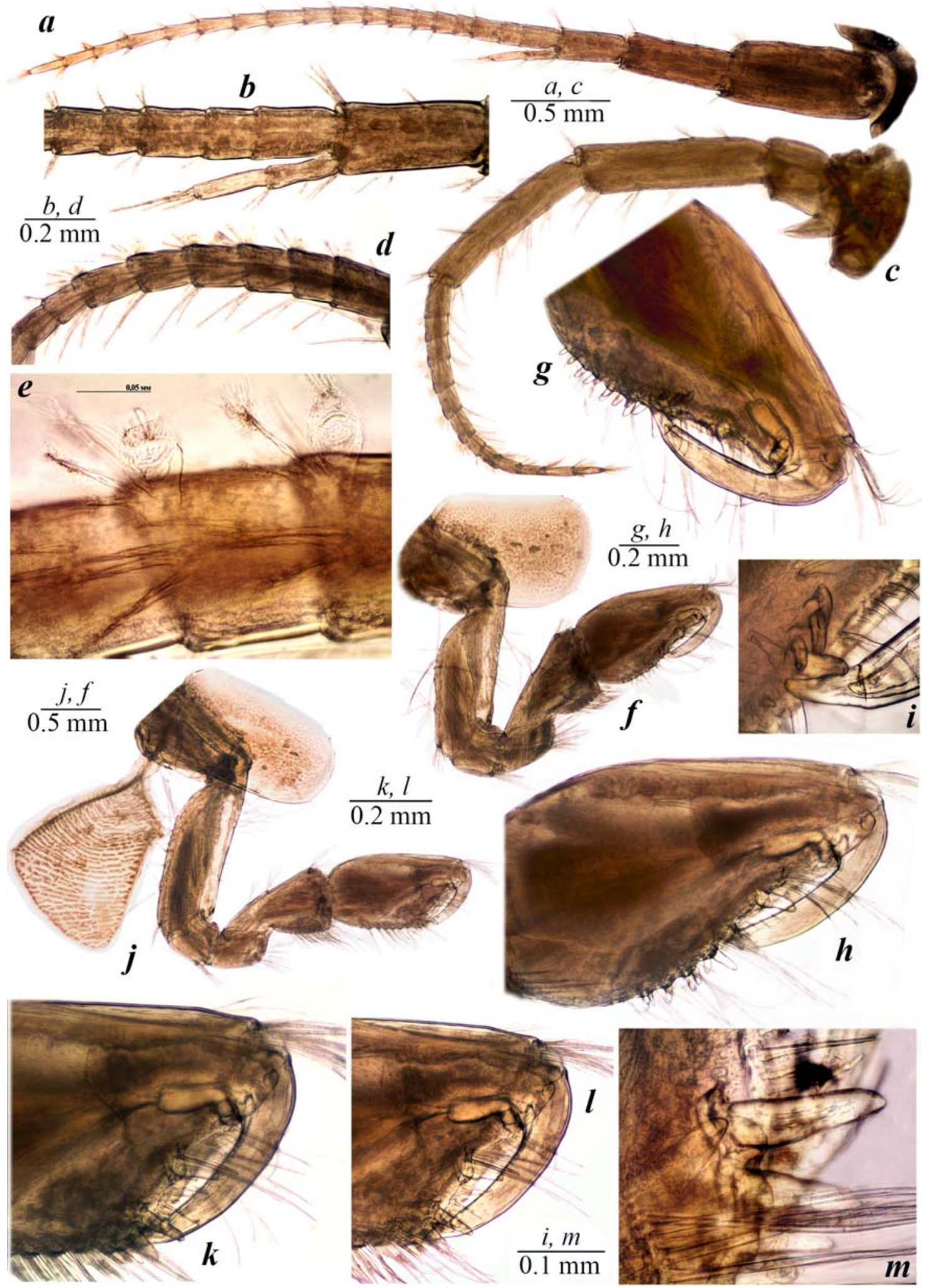

Fig. 1. Gammarus martynovi sp.n., male: $a$ - antenna I; $b$, - same, additional flagellum; $c$ - antenna $2 ; d$, $e$ - same, flagellum; $f$ gnathopod $1(\mathrm{GI}) ; g, h$ - palm of G1; $i$ - distoventral corner of palm of G1; $j$ - gnathopod 2 (G2); $k, l$ - palm of G2; m, distoventral corner of palm of $\mathrm{G} 2 ; m-$ distoventral corner of palm of $\mathrm{G} 2$.

Рис. 1. Gammarus martynovi sp.n., самец: $a$, - антенна I; $b-$ то же, добавочный жгутик; $c$ - антенна $2 ; d$, $e-$ то же, жгутик; $f$ - гнатопод 1 (GI); $g, h$ - клешня $\mathrm{G} 1 ; i$ - дистовентральный угол клешни $\mathrm{G} 1 ; j$ - гнатопод 2 (G2); $k, l$ - клешня $\mathrm{G} 2 ; m-$ дистовентральный угол клешни $\mathrm{G} 2$. 


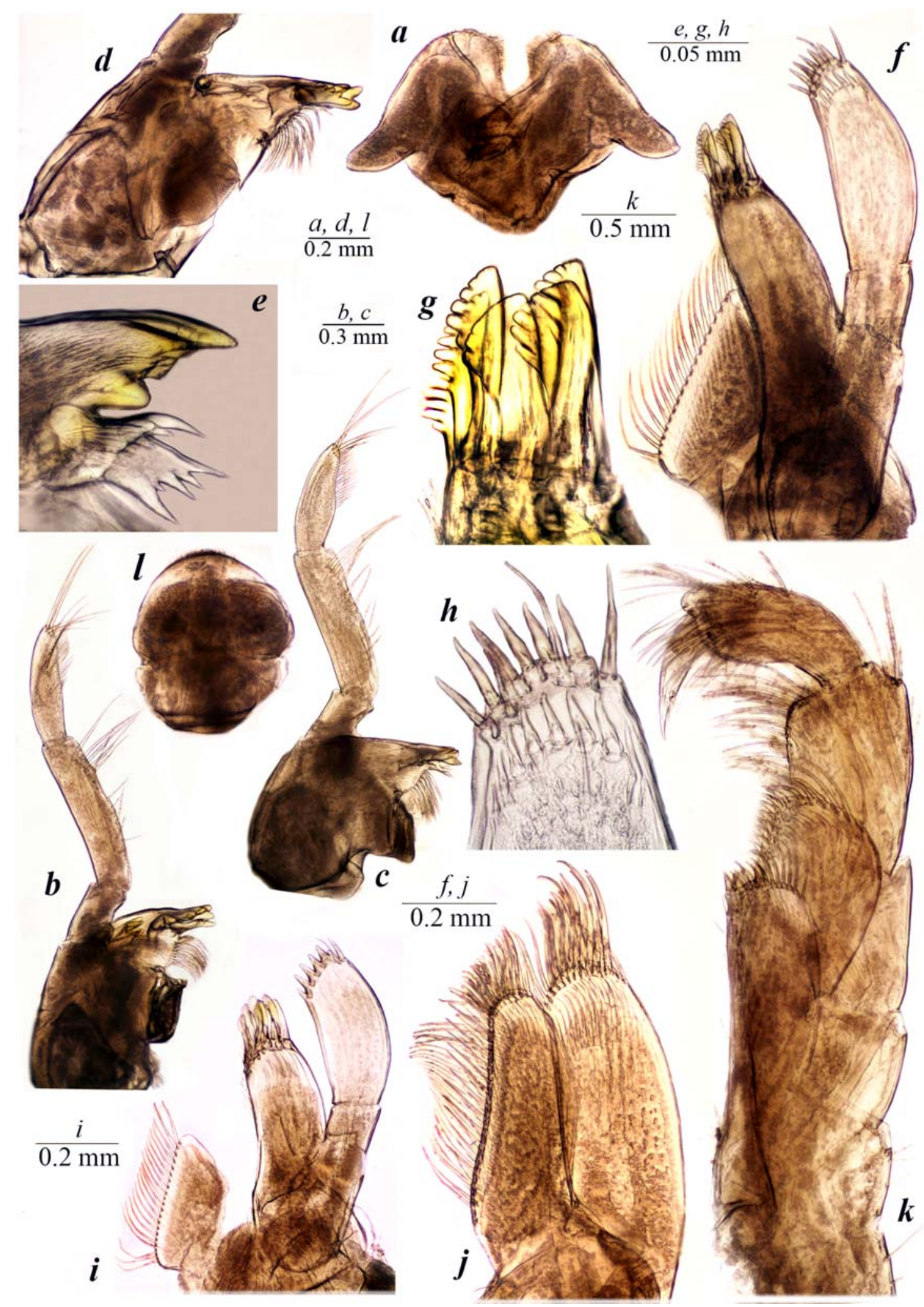

Fig. 2. Gammarus martynovi sp.n., male: $a$ - upper lip; $b, c-$ mandible (left and right); $d$ - left mandible, basal segments; $e-$ same, incisor process and lacinia mobilis; $f, i$ - maxilla $1 ; g$ - same, outer plate; $h$ - same, inner plate; $j$ - maxilla $2 ; k$ - maxilliped; $l$ - lower lip.

Pис. 2. Gammarus martynovi sp.n., самец: $a$ - верхняя губа; $b, c$ - мандибулы (левая и правая); $d$ - левая мандибула, базальный членик; $e$ - то же, режущий край и lacinia mobilis; $f, i$ - максилла $1 ; g$ - то же, наружная пластина; $h$ - то же, внутренняя пластина; $j$ - максилла $2 ; k$ - максиллипед; $l$ - нижняя губа. 


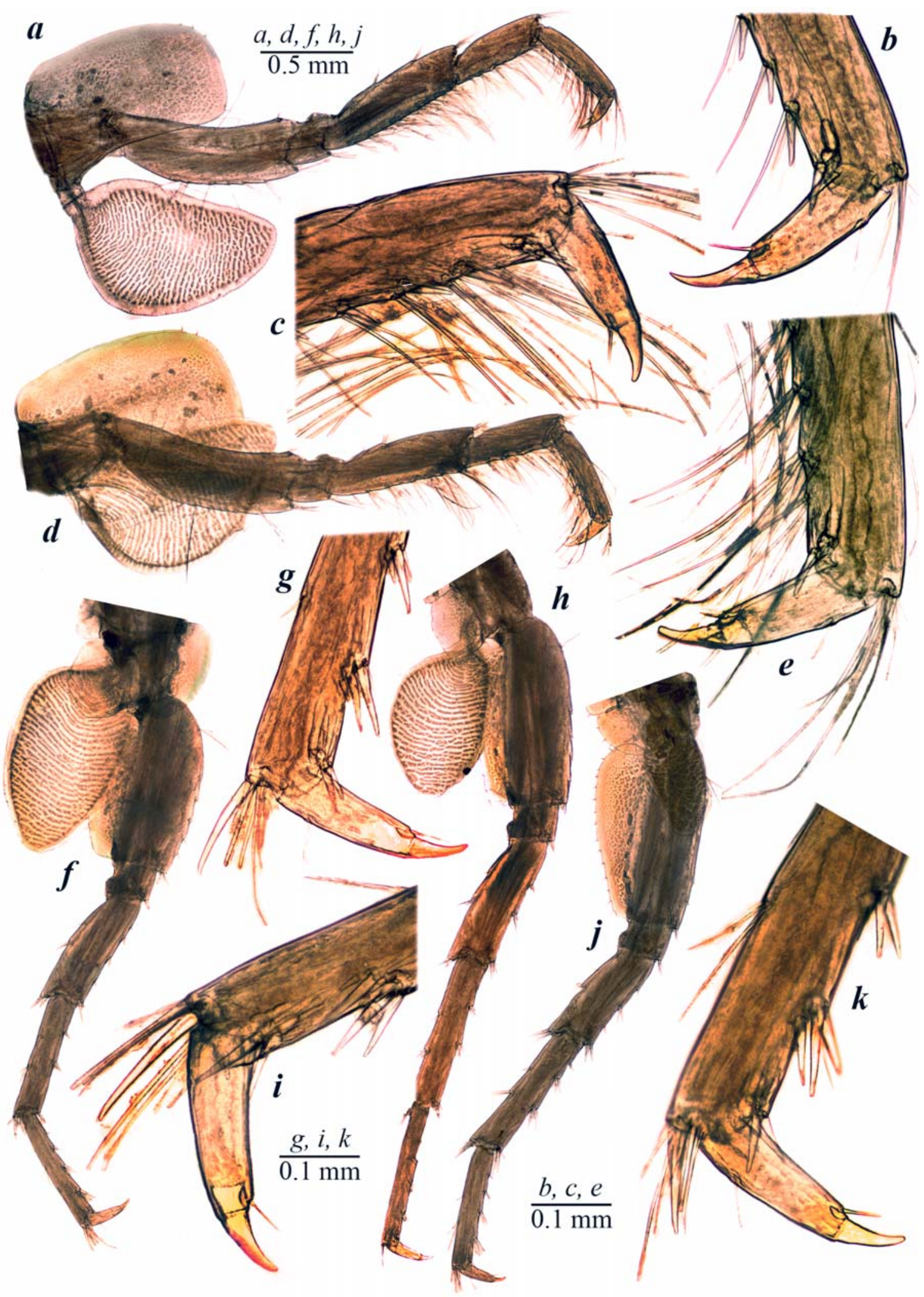

Fig. 3. Gammarus martynovi sp.n., male: $a$ - pereiopod 3; $b, c$ - same, dactylus; $d$ - pereiopod 4; $e$ - same, dactylus; $f-$ pereiopod 5; $g$ - same, dactylus; $h$ - pereiopod $6 ; i$ - same, dactylus; $j$ - pereiopod $7 ; k$ - same, dactylus.

Pис. 3. Gammarus martynovi sp.n., самец: $a$ - переопода $3 ; b, c$ - то же, дактилус; $d$ - переопода 4; $e$ - то же, дактилус; $f$ переопода $5 ; g$ - то же, дактилус; $h$ - переопода $6 ; i-$ то же, дактилус; $j$ - переопода $7 ; k$ - то же, дактилус. 
plate 6 with 1 small setae on anterior lobe and 2 setae on posterodistal corner (Fig. $3 h$ ). Coxal plate 7 with 1 small setae on anterior lobe and 5-6 setae on posterior margin (Fig. 3j). Coxal gills 2-7 well developed.

Gnathopod 1 (G1) (Fig. 1f) with basis about twice as long as wide, with long setae on both anterior and posterior margins; ischium and merus rectangular; carpus triangular in shape, elongated, with long setae on anterior margin; palm (Fig. $1 g-i$ ) oblique, bearing 1 blunt median spine and numerous smaller blunt spines (up to 12) along palmar angle; dactylus with one seta on its outer margin.

Gnathopod 2 (G2) (Fig. 1j) with ischium and merus rectangular; carpus triangular in shape, elongated, with long setae on anterior and ventral margins; palm (Fig. $1 k, l$ ) subrectangular, with oblique distal margin, with long setae ventral margin, median spine present (Fig. 1l), with $2+1$ large spines on distoventral margin (Fig. $1 \mathrm{~m}$ ); dactylus with 1 seta on outer margin.

Pereopods 3-4 (P3-4) (Fig. 3a, d) with rather robust segments covered with long setae, not folded distally; basis about 2.5 times as long as wide; ischium quadrate; merus about 3 times as long as wide, with long setae along ventral margin and short setae dorsally; carpus about twice as long as wide, sparsely setose along their ventral margin; propodus about 5 times as long as wide, with small spines along ventral margin (Fig. 3b, c); dactylus relatively stout, blunt, with 1 serrated seta on outer margin and 1 seta at joint of unguis.

Pereopods 5-6 (P5-6) (Fig. 3f, $h$ ) with relatively stout segments; basis about 1.5-2 times as long as wide, with short spines and setae along dorsal and ventral margins; ischium quadrate, with spines at distodorsal corner; merus and carpus about $2.5-3$ times as long as wide, armed with relatively stout spines along dorsal and ventral margins; propodus about 5 times as long as wide, with stout small spines along ventral margin; dactylus (Fig. $3 g, i$ ) stout, with stout unguis, with 1 serrated seta on outer margin and 1 setae at joint of unguis.

Pereopod 7 (P7) (Fig. 3j) with basis about 1.5-2 times as long as wide, with short setae along dorsal and ventral margins, with 4 long simple setae on the ventral part of surface on the segment, distoventral angle rounded, without lobe, the posterior edge in the lower part straight, without a notch; ischium quadrate, with spines at distodorsal corner; merus about twice as long as wide; carpus about 2.5-3 times as long as wide, armed with relatively stout spines along dorsal and ventral margins; propodus about 5 times as long as wide, with stout small spines along anterior margin; dactylus (Fig. $3 k$ ) stout, with stout unguis, with 1 serrated seta on outer margin and 1 setae at joint of unguis.

Epimeral plate 1 (Fig. $4 a$ ) oval ventrally, non-dilated on distal margin, with 8 long setae on anteroventral margin and 5 short setaå on posteroventral margin. Epimeral plates 2 and 3 with elongated ventroproximal corner (Figs 4b,d). Epimeral plate 2 with 3 short setae on anteroventral corner and 5 setae along posterior margin (Fig. 4c). Epimeral plate 3 with $4+1$ short setae on anteroventral corner and $4+1$ setae along posterior margin.

Pleopods 1-3 (P11-3) (Fig. 4g, $i$ ) with peduncle bearing several long setae, with $2(\mathrm{Pl1}, 2)$ or $3(\mathrm{Pl} 3)$ retinacula accompanied by $2(\mathrm{Pl} 3)-4(\mathrm{P} 11,2)$ setae; rami with about $16-$ 20 segments, fringed with plumose setae.

Urosomites 1-3 almost flat; each urosomite with a dorsomedial and two dorsolateral groups of spines on their posterior margins (Fig. $5 d, e$ ). The dorsolateral armature of urosomites 1-2 (Fig. 5d, e) consists of 1-2 spines $+2-3$ setae and 2 spines $+3-4$ setae, respectively; setae shorter than spines. Urosomite 3 with dorsolateral groups consisting of 1-2 spines and dorsomedial group of 1-2 setae only.

Uropod 1 (Fig. $4 k$ ) with peduncle longer than rami, with 3 spines distally and 3 spines on outer margin; inner margin with 1 marginal and 1 distal spine; outer ramus slightly shorter than inner ramus, with 2 distal spines and 3 groups of median spines; inner ramus with 2 distal spines and 1 groups of median spines. Uropod 2 (Fig. 4l): peduncle with 1 and 3 marginal spines on inner and outer margin, and 2 distal spines; outer ramus slightly shorter than inner ramus, with 4 distal spines, 1 spine on outer margin and 1 spine on inner margin; inner ramus with 4 distal and 2 groups of spines on inner margin. Uropod 3 (Fig. $3 \mathrm{~m}$ ): peduncle with 3-5 subdistal spines; inner ramus shorter than outer ramus (about $1 / 5$ of the length), covered with numerous long simple and plumose setae (Fig. 6f), with 2 large lateral and small subdistal spines, article 2 (Figs $3 n, 5 i$ ) of outer ramus small, elongated, with long subdistal simple setae. Endopodite and exopodite of U3 with bristles (plumose setae); about one in a bundle on the outer side of exopodite, accompanying by $2-3$ simple bristles; distal segment of exopodite armed with simple setae, without bristles.

Telson (Figs $4 f, 5 h, 6 d$ ) excavated almost to the base; each lobe with 1 or 2 distal spines together with 4-5 longer distal setae and 1-2 lateral single setae (Figs $4 f, 5 h$ ); the length of distal and lateral setae about 0.5 and 0.25 times as long as the length of telson, respectively.

GENBANK ACCESSION NUMBERS. MT107251, MT107252.

TAXONOMIC REMARKS. Based on molecular genetic data (marker fragment of COI mtDNA) the new species is related and at the same time well separated within the phylogenetic clade including G. lacustris, G. inberbus, G. decorosus, G. pseudosyriacus, G. crinicaudatus and some other Gammarus species described from south-western Turkey to Tibetian plateau (see Fig. 7) (after Clewing et al., 2016; Hou, Li, 2018). The species belong to well supported sister clade to Gammarus lacustris G.O. Sars, 1863 and genetically mostly related to this species (see Fig. 7). At the same time, the new species is mostly morphologically similar to Gammarus subaequalis (Martynov, 1935) reported by Birštein [1948] from Hissar (Gissar) Mountains in Tajikistan but described by Martynov [1935] from Galkino near Shimkent (the basin of Syr Darya River in Kazakhstan) (unfortunately, no genetic data are presented for these species).

Comparison of the new species with the typical Gammarus subaequalis Martynov, 1935 is difficult because of the inaccurate description and the absence of the type material of the latter species. The new species can be separated from Syr Darya specimens by shorter flagellum (20 articles vs. $30+$ in G. subaequalis) and very small distal article (article 3) of additional flagellum of A1; different number of teeth on outer plate of MI; the presence of setae on the inner side of basis of P7 [Karaman, Pinkster, 1977; Karaman, 1991] mentioned this feature as an essential); another form of basipodites of P5-7: they are wider and less narrowed downwards, only basipodite of P6 notched at the posterior margin, its distal angle distinctly projected; shorter and thickened dactyli of P5-7; only 3 (vs. 4 groups mentioned by Martynov [1935]) groups of dorsal spines on urosomites 13 ; more slender form of telson and less armament of its surface; smaller distal segment of outer ramus and some- 

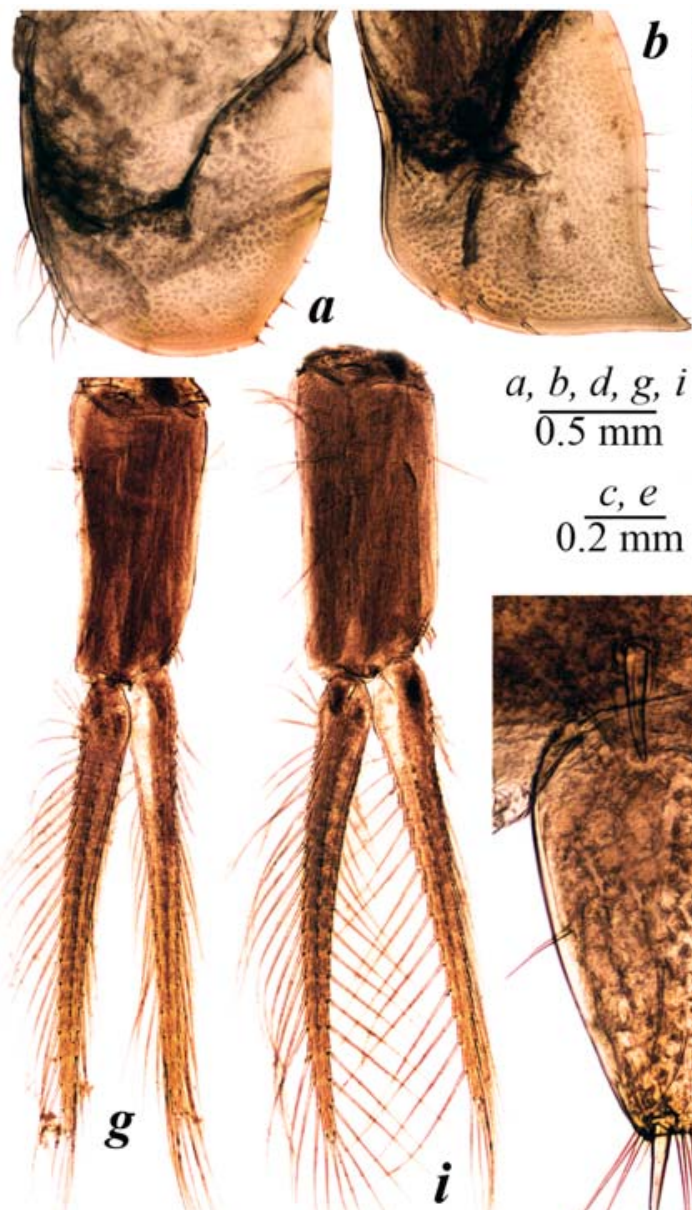

$a, b, d, g, i$ $\overline{0.5 \mathrm{~mm}}$
$0 . \frac{c, e}{2 \mathrm{~mm}}$

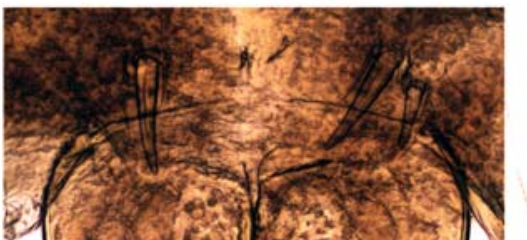

(1)
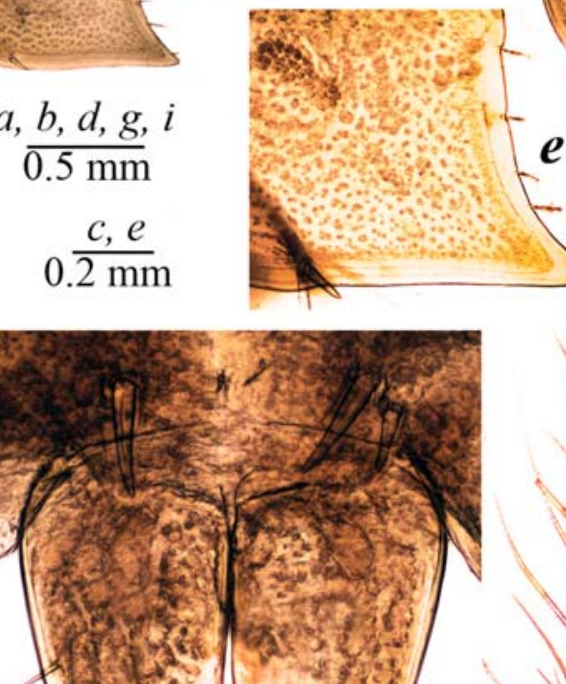

$\boldsymbol{e}$

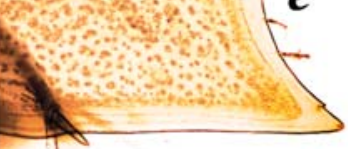

11

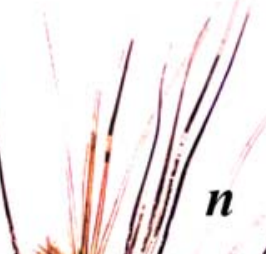

fisto

(1)
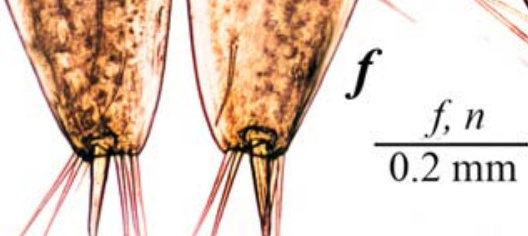

$\frac{k-m}{0.5 \mathrm{~mm}}$

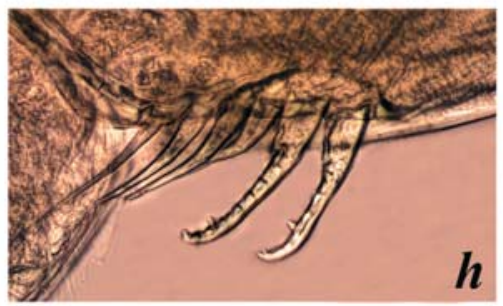

$\boldsymbol{h}$
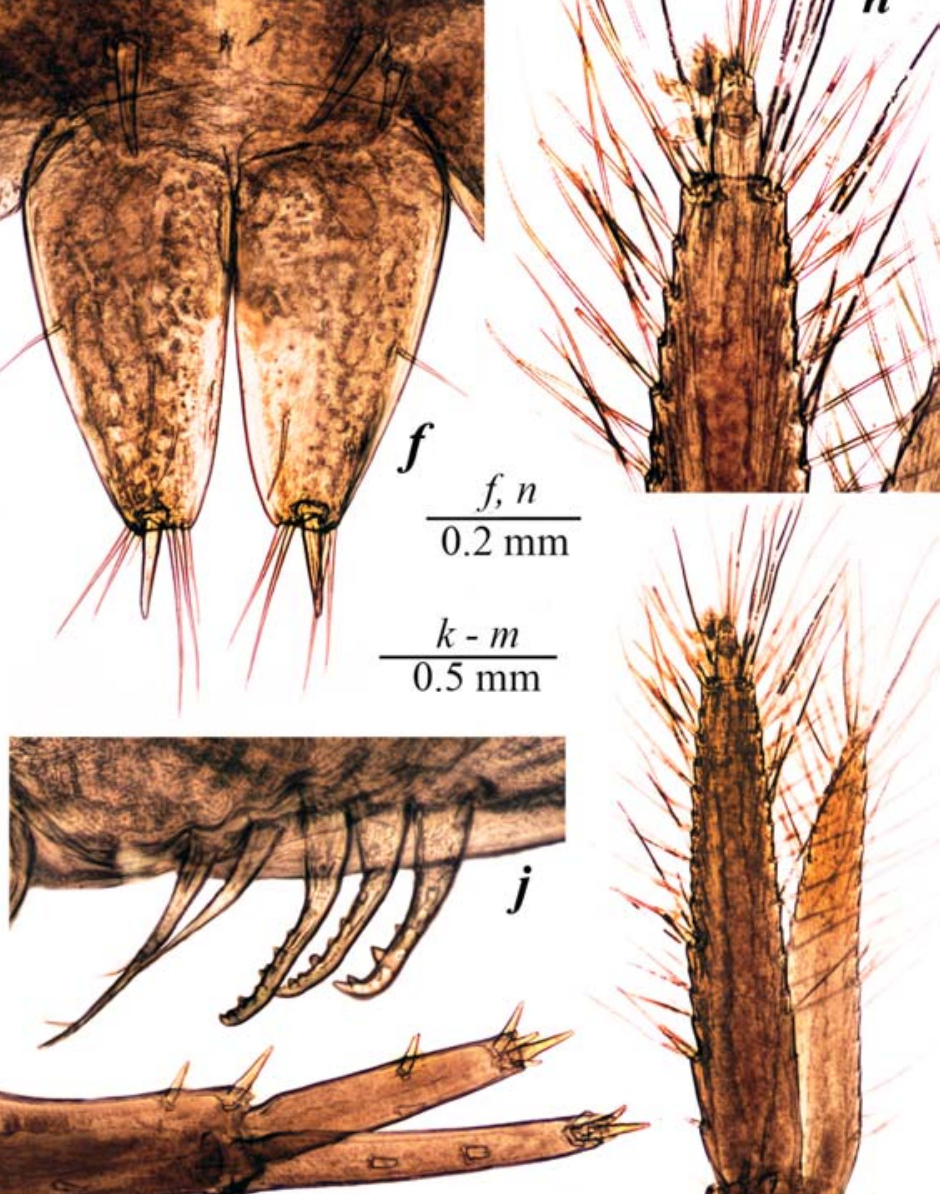

1

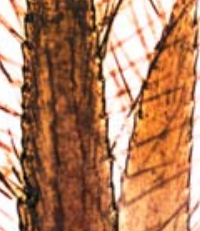

$\frac{h}{0.05 \mathrm{~mm}}$

\section{$\frac{j}{0.05 \mathrm{~mm}}$}
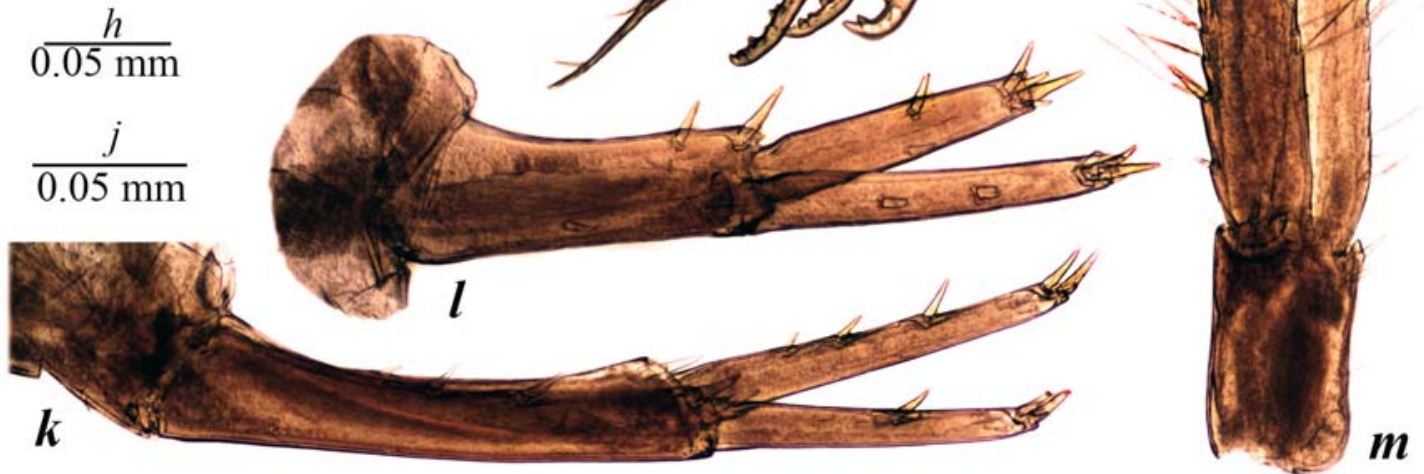

Fig. 4. Gammarus martynovi sp.n., male: $a$ - epimeral plate $1 ; b$ - epimeral plate $2 ; c-$ same, ventro-proximal angle; $d$ - epimeral plate $3 ; e$ - same, ventro-proximal angle; $f$ - telson; $g$ - pleopod $2 ; h$ - same, retinacles; $i$ - pleopod $3 ; j-$ same, retinacles; $k$ uropod I; $l-\operatorname{uropod} 2 ; m-\operatorname{uropod} 3 ; n-$ same, distal segment of outer ramus.

Рис. 4. Gammarus martynovi sp.n., самец: $a$ - эпимеральная пластина $1 ; b-$ эпимеральная пластина 2 ; $c$ - то же, вентропроксимальный угол; $d$ - эпимеральная пластина $3 ; e$ - то же, вентро-проксимальный угол; $f$ - тельсон; $g$ - плеопод $2 ; h$ - то же, ретинакулы; $i$ - плеопод $3 ; j$ - то же, ретинакулы; $k$ - уропод I; $l$ - уропод $2 ; m-$ уропод $3 ; n-$ то же, дистальный сегмент наружной ветви. 


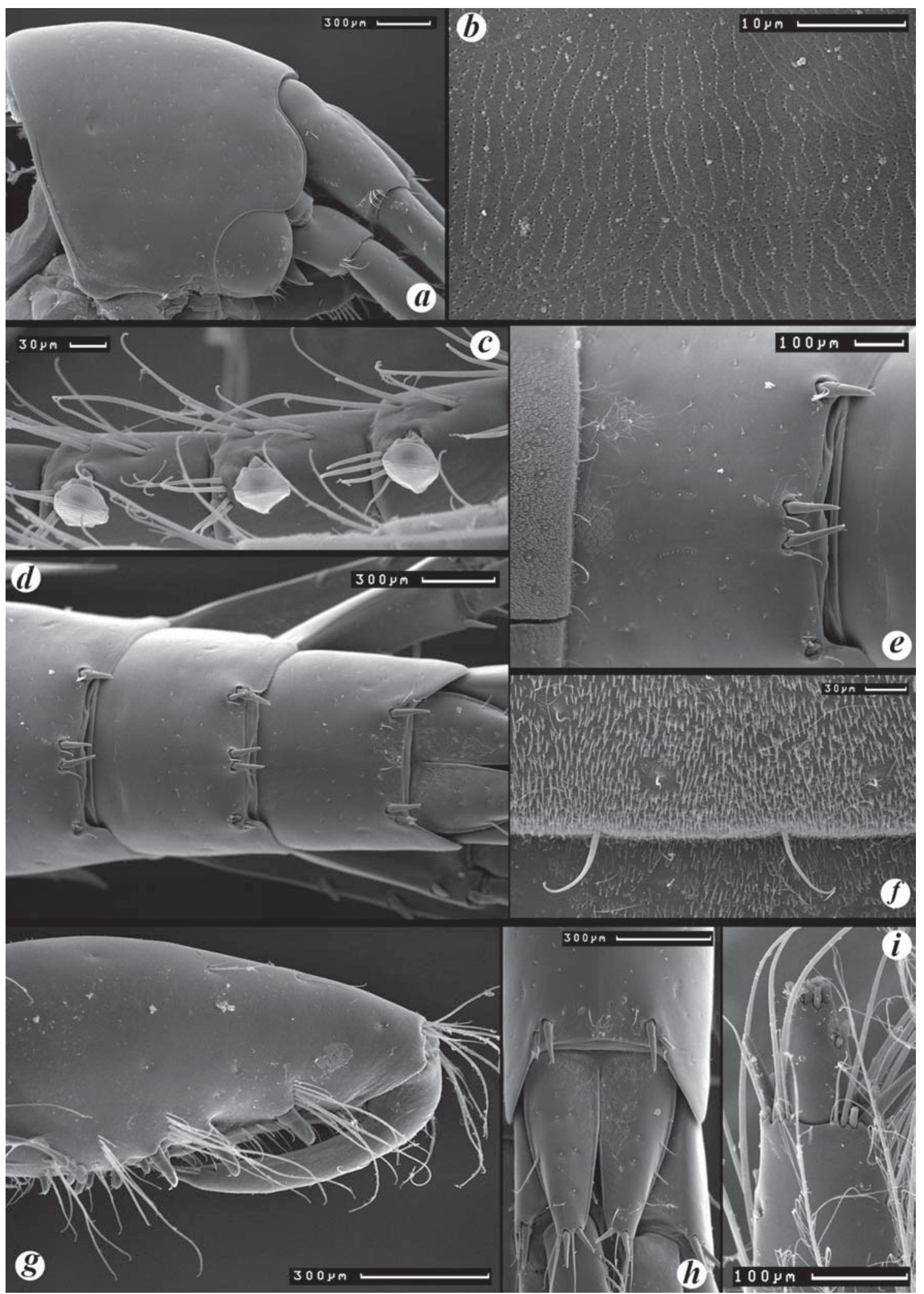

Fig. 5. Gammarus martynovi sp.n., male: $a$ - head; $b-$ ultrastructure of head; $c$ - calceoli of antenna $2 ; d-$ urosomites $1-3$, dorsal view; $e$ - urosomite $1 ; f$ - distodorsal margin of coxal plate $7 ; g$ - palm of gnathopod $2 ; h$ - distal margin of urosomite 3 and telson; $i$ distal segment of outer ramus of uropod 3.

Рис. 5. Gammarus martynovi sp.n., самец: $a$ — голова; $b$ - ультраструктура поверхности головы; $c$ — кальцеолы антенн $2 ; d-$ уросомиты $1-3$, дорсально; $e$ - уросомит $1 ; f$ - дистодорсальный край коксальной пластины $7 ; g$ - клешня гнатопод $2 ; h-$ дистальный край уросомита 3 и тельсон; $i$ - дистальный сегмент наружной ветви уропод 3. 


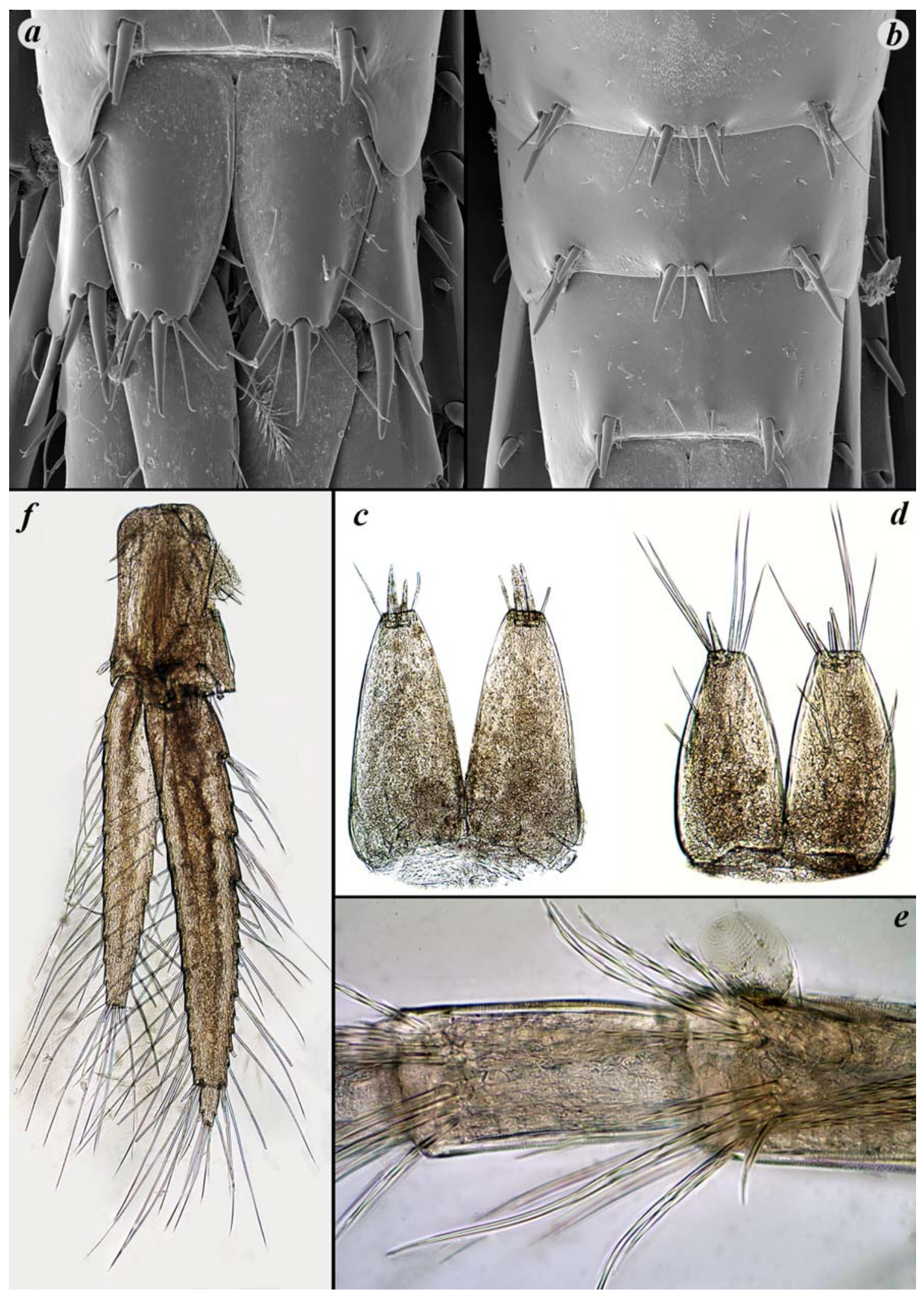

Fig. 6. Gammarus lacustris (Sars, 1863), male from Zorkul Lake, Pamir (a-c), and Gammarus martynovi sp.n., male $(d-f): a, c, d-$ telson; $b$ - dorsal surface of pleonites; $e-$ calceoli of antenna $2 ; f$ - uropod 3.

Рис. 6. Gammarus lacustris (Sars, 1863), самец из оз. Зоркуль, Памир (a-c), и Gammarus martynovi sp.n., самец $(d-f): a, c, d-$ тельсон; $b$ - дорсальная сторона плеонитов; $e$ - кальцеолы антенн $2 ; f$ - уроподы 3. 


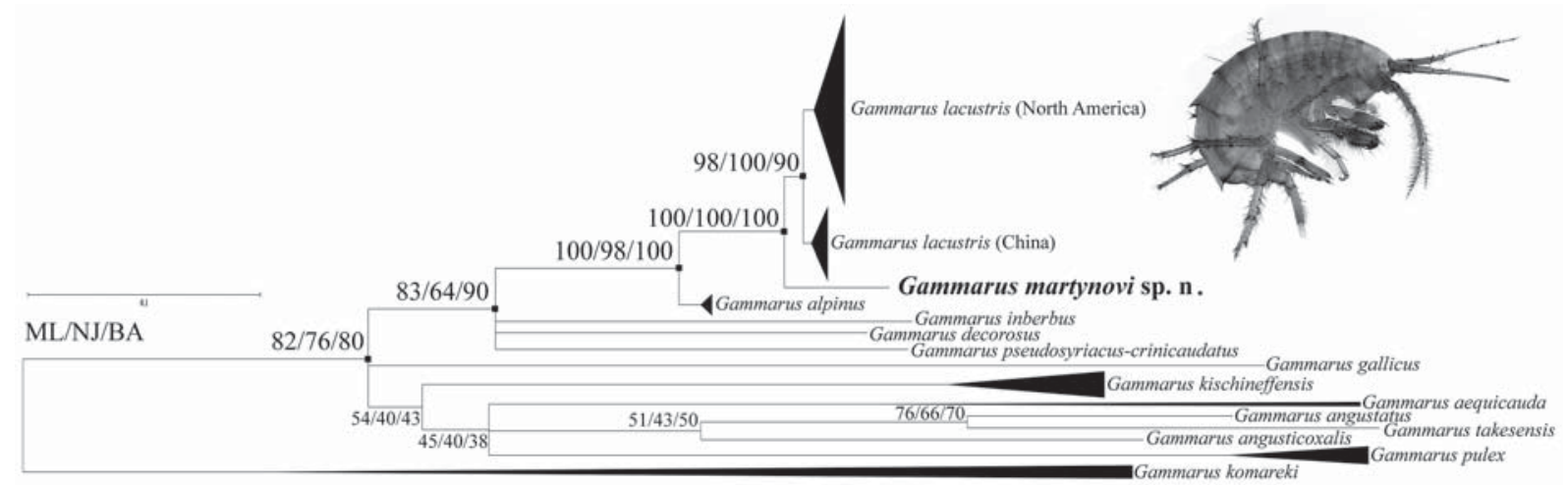

Fig. 7. Phylogenetic reconstruction (tree) (COI mtDNA) of relative Gammarus species (“pulex" group). Bootstrap support — ML/NJ/BA.

Рис. 7. Филогенетическая реконструкция (на основе генного маркера COI мтДНК) близкородственных видов рода Gammarus (группа "pulex"). Поддержка клад — ML/NJ/BA.

what concave form inner ramus of $\mathrm{U} 3$; the presence of 3 retinacules on $\mathrm{P} 13$ (vs. 2 retinacules in G. subaequalis).

From very widely distributed and quite variable G. lacustris (Fig. $6 a-c$ ), the new species can be also separated by shorter flagellum of A1; different armature of outer plate of MI; straight basipodites of P5-7 at least in the lower 2/3 and the presence of setae on the inner side of basis of $\mathrm{P} 7$; different armament of telson surface (see Fig. $6 c, d$ ); the presence of 3 retinacules on $\mathrm{Pl} 3$ (vs. 1 or 2 in Chinese $G$. lacustris) and the presence of simple and plumose setae on uropod 3 (only plumose in G. lacustris) (see Takhteev \& Mekhanikova, 2000; Mekhanikova, 2009).

From the populations from Turkmenistan (Garlyk) (after Sidorov et al., 2018), probably belonging to Gammarus lacustris (using GenBank sequences - MG655630), the new species is distinguished by a smaller number of segments in the main and an additional flagellum of A1 and shorter flagellum of A2; other armament of G1 (smaller spines and their other location); more enveloped P3-4 (not noticeable in young individuals and females); shorter and thickened dactyli of P5-7, the presence of setae on the inner side of basipodite of P7; poorer telson and urosome armature; the presence of 3 retinacules on $\mathrm{Pl} 3$.

From Gammarus syriacus Chevreux, 1895, similar to $G$. subaequalis, the new species differs in many morphological features (mostly mentioned above) such as armature of urosome and anterior margin of basipodites of P5-7, form of epimeral plates, etc. The phylogenetic relationship and synonymizaton of $G$. syriacus and $G$. subaequalis is generally questionable.

Moreover, the new species is also separated from $G$. syriacus and other mentioned species geographically inhabiting the spring at the small tributary of the Panj River, which flows into Amu Darya from which basin no species of the genus Gammarus has yet been described.

ETYMOLOGY. The new species is named in honor of the famous Russian paleontologist and zoologist described numerous freshwater crustacean species from the territory of the former Soviet Union - Dr. Andrey Vladimirovich Martynov (21.08.1879 - 29.01.1938).

HABITAT. The specimens of the new species were found in a small thermal spring Dzhaushangoz, $37^{\circ} 21^{\prime} 59.83^{\prime \prime} \mathrm{N}$ $72^{\circ} 21^{\prime} 55.31^{\prime \prime} \mathrm{E}$, located at an altitude of $3357 \mathrm{~m}$ above sea level in Pamir Mountains. Water temperature varies in different parts of the stream from 15 to $20{ }^{\circ} \mathrm{C}$.
DISTRIBUTION. The species is presently known from the type locality in the headwaters of the Shakhdara River, a small tributary of the Panj River, in the Roshtqal'a District of the Gorno-Badakhshan Autonomous Region of Tajikistan.

Acknowledgements. The study is supported by the Russian Foundation for Basic Research (RFBR) (grant No. 1834-20105 mol a ved). Authors are very thankful to Dr. V.V. Takhteev (Irkutsk State University) for the valuable remarks to the manuscript.

\section{References}

Birštein J.A. 1945. [Notes on the freshwater higher crustaceans of Turkmenia and Iran] // Uchenye zapiski MGU. Biologiya. Vol.83. P.151-164 [in Russian].

Birštein J.A. 1948. [Amphipoda of Tajikistan] // Pamyati akademika Sergeya Alekseevicha Zernova. Moscow, Leningrad: AN SSSR Publ. P.263-273 [in Russian].

Clewing C., Wilke T., Albreche C. 2016. Phylogenetic patterns of freshwater amphipods inhabiting the Tibetan Plateau // Crustaceana. Vol.89. P.239-249. https://doi.org/10.1163/1568540300003518

Folmer O., Black M., Hoeh W., Lutz R., Vrijenhoek R. 1994. DNA primers for amplification of mitochondrial cytochrome c oxidase subunit I from diverse metazoan invertebrates // Molecular Marine Biology and Biotechnology. Vol.3. P.294-299.

Hou Z., Li S. 2018. Four new Gammarus species from Tibetan Plateau with a key to Tibetan freshwater gammarids (Crustacea, Amphipoda, Gammaridae) // ZooKeys. Vol.747. P.1-40. https://doi.org/10.3897/zookeys.747.21999

Karaman G.S. 1971. Beitrag zur Kenntnis der Amphipoden. XIX. Eine neue Art der Gattung Sarothrogammarus (Gammaridae) aus Afghanistan, S. ruffoi n. sp. // Crustaceana. Vol.20. No.2. P.199-207.

Karaman G.S. 1991. The survey of described and cited freshwater Gammarus species (Fam. Gammaridae) from Soviet Union with redescription of two taxa (Contribution to the knowledge of the Amphipoda 205) // Poljoprivreda i Šumarstvo. Vol.37. P.37-73.

Karaman G.S., Pinkster S. 1977. Freshwater Gammarus species from Europe, North Africa and adjacent regions of Asia (Crustacea, Amphipoda), part 1. Gammarus pulex-group and related species // Bijdragen Tot De Dierkunde. Vol.47. P.1-97.

Martynov A.V. 1935. [Amphipoda Gammaridea of the running waters of Turkestan] // Trudy Zoologicheskogo Instituta AN 
SSSR, Leningrad. Vol.2. P.411-508 [in Russian with English summary].

Martynov A.W., Behning A.L. 1948. [On Some Central Asiatic Gammarids] // Trudy Zoologicheskogo Instituta AN SSSR, Leningrad. Vol.7. P.171-176 [in Russian].

Mekhanikova I. 2009. [Morphology of Gammarus dabanus Tachteew et Mekhanikova, 2000 (Crustacea, Amphipoda, Gammaridea) from mountain streams of the Khamar-Daban Ridge (Zabaikalye)] // Invertebrate Zoology. Vol.6. No.1. P.21-31 [in Russian, with English summary].

Sidorov D.A., Gontcharov A.A., Palatov D.M. 2013. Unexpected finding of the invasive Baikalian amphipod Gmelinoides fasciatus in a cold spring of the southern Pamir Mountains //
Knowledge and Management of Aquatic Ecosystems. Vol.411. P.12p1-12p8. https://doi.org/10.1051/kmae/2013079

Sidorov D., Hou Z., Sket B. 2018. Three new remarkable amphipod species (Crustacea: Gammaridae) from springs and subterranean waters of Central Asia // Zootaxa. Vol.4444. No.4. P.437-461. http://doi.org/10.11646/zootaxa.4444.4.5

Takhteev V.V., Mekhanikova I.V. 2000. [New species of the sideswimmers (Crustacea Amphipoda) from the mountain streams of Khamar-Daban ridge] // Issledovaniya vodnykh ecosystem Vostochnoy Sibiri. Bioraznoobrazie Baikalskogo regiona. Trudy Biologo-Pochvennogo fakulteta IGU. Vol.3. P.115-124 [in Russian].

Responsible editor V.A. Spiridonov 